\title{
Architecture and Spatial Practices in Post-Communist Minsk: \\ Urban Space under Authoritarian Control
}

NATALIA BARYKINA

\section{INTRODUCTION}

I left my hometown of Minsk, Belarus in October 2003. The following summer the European Humanities University was shut down by the government of Aleksander Lukashenko. Along with many other intellectuals, many of my friends, colleagues and professors left, and continue to leave, the country. As a part of the dispersed EHU community and a part of a wave of student emigration, I work, think and live in very different cultural surroundings than those who stayed, voluntarily or otherwise, in Belarus. The place of one's intellectual speculations does matter; criticizing the Belarusian government is a criminal offense in Belarus but I will not be imprisoned nor expelled from university for doing it in Canada. As Joan Scott notices, however, when experience is taken as "the originary point of explanation," it ignores the problem that the position of the subject, her/his vision, is already structured by various discourses (26-8). So I am not sure if "not being there" serves as a limitation or an enrichment of my research, or both simultaneously. As much as I am not there in the process of "producing" the place, I am its continual product, insofar as the city produced me and continues to engage my imaginative and scholarly capacities.

My former hometown, Minsk, is the capital of the Republic of Belarus, one of the former Soviet republics that gained independence in 1991. What makes this city so intriguing a place of inquiry is its recent history: Minsk was completely destroyed during WWII and rebuilt in the style that art historians refer to as "Stalinist Empire," which emphasizes squares, monuments, grand boulevards, and massive state buildings. However, with a population nearing two million, Minsk is seldom considered a city of any major economic or cultural significance. Post-war Minsk offered a rare opportunity for Stalinist urban designers to plan a city entirely according to Soviet 
interpretations; the city was a sort of historical urban tabula rasa on which to write. As a result, its architecture reflects a historical layering of communist and some consumer-capitalist designs. For example, the monument of Lenin, once symbolic of Soviet power, remains ironically in front of the House of Government on Independence Avenue, despite official disavowals of communist ideology. Lenin neighbors a Catholic church, a strip club, the four-star Hotel Minsk, the Main Post Office, the buildings of the campus of the Belarusian State University and a newly constructed underground shopping mall. In this respect, Minsk can be compared to Warsaw, which Magdalena J. Zaborowska describes as "a fascinating hybrid: of World War II memorials, painstakingly reconstructed past splendor, and communist grayness and grotesque monumentality, as well as the new office parks, fast food restaurants, chain hotels, and omnipresent billboards that mark or mar the post-1989 period" (98). Whereas in other former Soviet-bloc capitals the remaining Soviet monuments or buildings co-exist with capitalist towers, chain restaurants, and hotels, in contemporary Minsk the contrast between communist and capitalist urban elements and design is not yet so stark. In some sense, this should make a city a "museum" of Soviet architecture, although, unlike Berlin, for example, it lacks a reflexive relation to its own history (there is no tourist industry to speak of). Unlike Warsaw, Prague, Budapest, or even Bucharest, it has not received the massive injections of capital or legislative and social integration that EU membership would secure, nor has its economy been integrated into global capitalist society in the same ways as those cities. At the same time, Minskdwellers and Belarusians think of themselves as having developed within a European - if distinctly Slavic - history, which distinguishes them culturally from Turkmenistan, Uzbekistan, Kazakhstan, and the other Asian republics once part of the Soviet Union. Clearly, a lengthier comparative critical approach is called for, a project that lies far beyond the scope of this article. My point here is simply to suggest that, partly because of the relative political and economic isolation of the country, Minsk, which was so radically remade, has developed in ways distinct from other Eastern European cities both before and after 1989. In this discussion, I focus primarily on Minsk over the past fourteen years, during the reign of the authoritarian government of Alexander Lukashenko. 


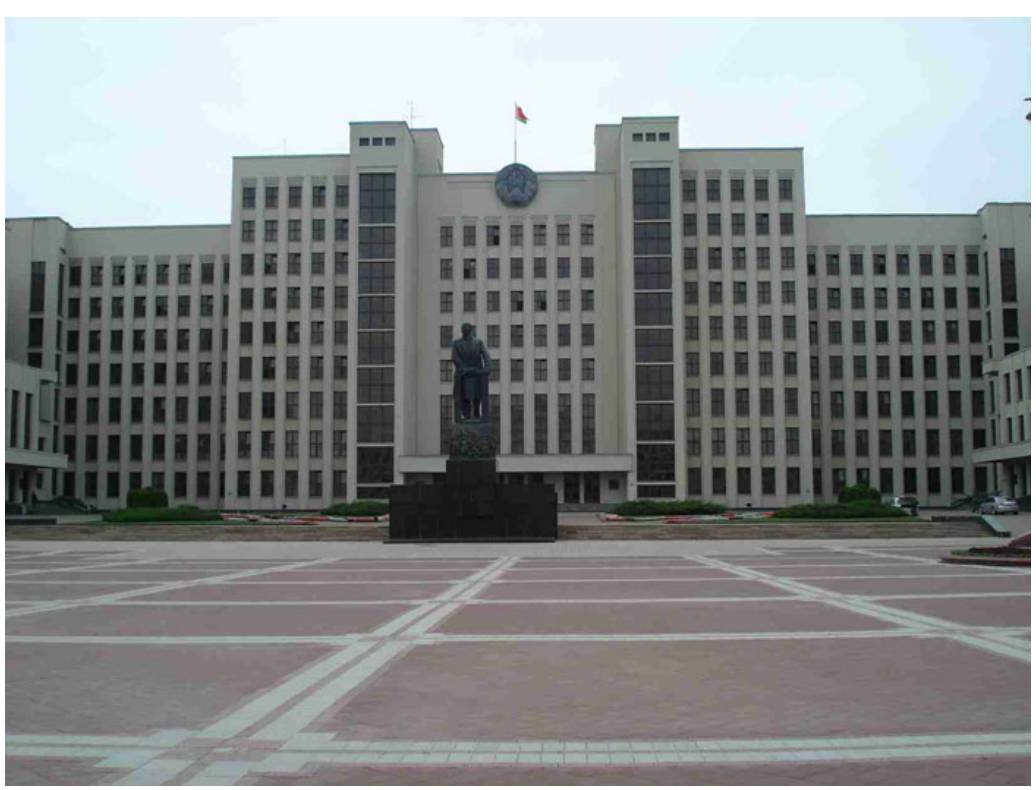

Fig. 1 Independence Square[1]

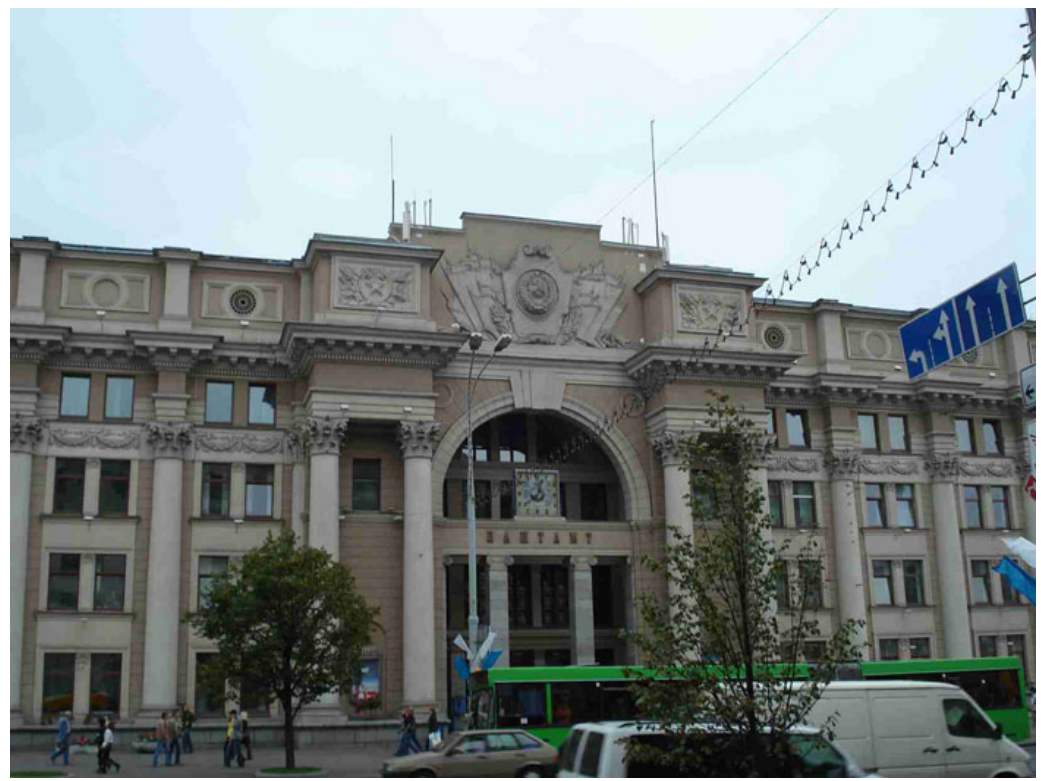

Fig. 2 Main Post Office 


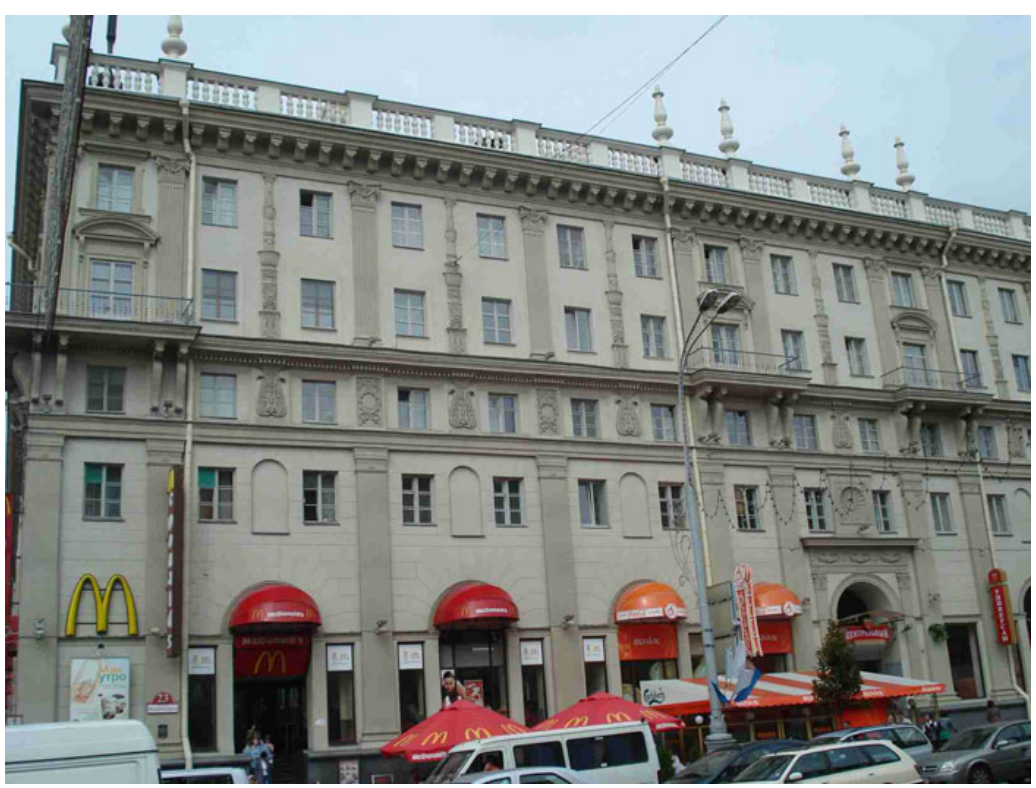

Fig. 3 McDonald's Restaurant

Here, an anecdote might help illustrate the need to incorporate critical urban geography into political analyses of post-1989 Eastern Europe. At the Street Life conference in Toronto in 2007, one of the presenters, Olena Nikolaenko, talked about the democratic revolution in Ukraine. She argued that during this event and the creation of the "tent city" in Kiev, streets became the only possible public venue for delivering political messages in an otherwise non-democratic regime. In focusing on this space as an exclusive vehicle of the democratic function of free speech, the street, in her presentation, was inadvertently reduced to the background for the events of the Orange Revolution, and attention soon shifted to the (rather interesting) semiotics of the political messages of the protesters. As Edward Soja warns, however, "we must be insistently aware of how space can be made to hide consequences from us, how relations of power and discipline are inscribed into the apparently innocent spatiality of social life, how human geographies become filled with politics and ideology" (6). For Nikolaenko, the street was simply an available space in which political messages could circulate. But how does that space become "available" in the first place? In other words, we might say, Soja implies that a thorough investigation of street politics should concentrate as much on the politics of spatiality as on the space of politics, which is what I attempt to do here. In the first section, I apply some of Henri Lefebvre's thinking to specific examples of collective practices 
in actual city spaces, such as the memorial at Nemiga subway station in Minsk. The memorial has been deeply controversial; debates surrounding the memorial exemplify how various parties make competing claims on urban space according to how they understand its social and practical uses. Further, contestation of the memorial's very design involves a struggle over conflicting understandings and applications of history and representation. In order to suggest the interactiveness of space that signals more than the mere acceptance or rejection of government or corporate ideology, the next two parts illustrate how urban space under authoritarian control is complexly lived, practiced, and resisted. In this respect, I focus on Oktiabrsky Square in downtown Minsk, which I follow with an analysis of the suburbs to illustrate how specifically Soviet spaces have been re-contextualized and contested in recent years.

\section{NEMIGA SUBWAY STATION: A LEFEBVRIAN APPROACH}

Critical geographers argue that the present discourse of space is often informed by the "naturalized" and therefore seemingly unproblematic spatial metaphors that the dominant discourses of power perpetuate: both reactionary discourses - emphasizing the rhetoric of origins, boundaries, invasion, purity/ contamination, centre/ margin, inside/ outside and so on - as well as progressive ones (Keith and Pile 19-21). This results in viewing space as passive, a neutral stage for action. These critics object to the very positioning of the category of space (as stasis) in a binary opposition to time (progress), thus depriving space of any political potential (Massey 142). Such considerations usually ignore social space and do not allow for the analysis of ideology and power. According to critical geographers, not only is space constituted through social relations and material social practices, but the way societies are organized spatially influences the way they function: "far from being the realm of stasis, space and the spatial are also implicated in the production of history and, thus, potentially in politics" (Massey 146). Let me narrow my focus to consider the influential work of Henri Lefebvre. According to Lefebvre, space is not a physical arena but emerges through a complex dialectics of the social relations of production. In order to analyze how space is produced, Lefebvre distinguishes among spatial practice, a combination of daily routine and urban realities; representations of space, "the space of scientists, planners, urbanists, technocratic subdividers and social engineers," (the scientific and institutionalized concepts of space, "the dominant space in any society"); and representational spaces (space directly lived through images and symbols, the realm of experienced cultural 
meanings that can be passively accepted or imaginatively transformed) (38-40). In Lefebvre's words, "a perceived-conceived-lived triad," loses all force if it is treated as an abstract "'model.' [...] Spatial practice, representations of space and representational spaces contribute in different ways to the production of space according to their qualities and attributes, according to the society or mode of production in question, and according to the historical period" (46). For example, in the Middle Ages in Europe, representational spaces of the everyday were interpretations of cosmological representations of space: "The road to Santiago de Compostela was the equivalent, on the earth's surface, of the way that led from Cancer to Capricorn" (Lefebvre 45). In other words, each historical period is characterized by a peculiar mode of production of space. Lefebvre argues that it is through the production of space that capitalism sustains itself, although he does not specify exactly how. Edward Soja goes further and applies this model to talk about the mode of production of capitalist spatiality which consists of "its peculiar production and reproduction of geographically uneven development via simultaneous tendencies toward homogenization, fragmentation, and hierarchization" (Postmetropolis 50).

In order to examine how the city space in Minsk is "perceived," "conceived" and "lived," we might consider the process of contemporary memorial construction.[2] A particularly interesting case involves the memorial at Nemiga subway station in Minsk, dedicated to the victims of a stampede which took place there during a rock concert in May 1999. The memorial is composed of a plaque that lists the names of the victims and a sculptural composition that consists of 53 bronze roses. During the concert, a heavy rain started unexpectedly, which resulted in a crowd of nearly 2000 people rushing into the nearby subway station for shelter. As a result, 53 people died, mostly teenage women, and more than 200 others were injured.[3] 


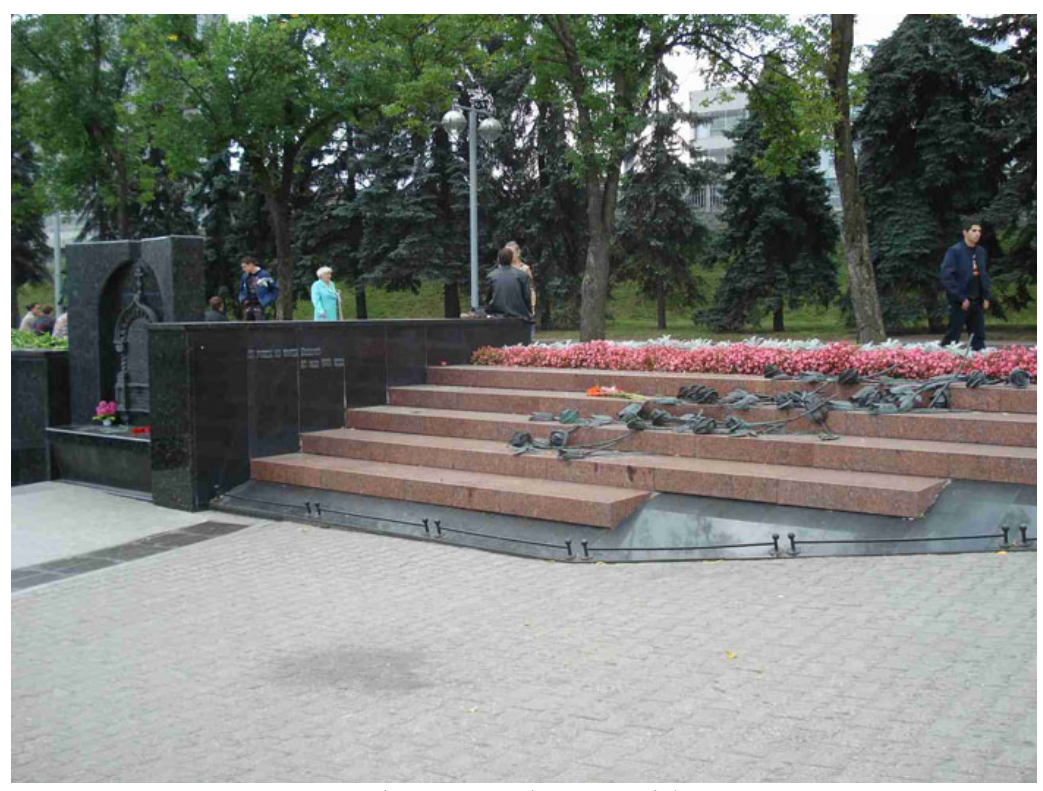

Figure 4. Nemiga Memorial.

The Nemiga district itself is a historically and symbolically saturated place, and we should consider how the representational or symbolic components of this part of the city are culturally experienced and understood. Urban mythology depicts the district of the subway station, where the Nemiga river used to flow and now is encased underground, as a historical centre of Minsk and, according to the Nemiga 99 website, as a "cursed" place. Seemingly in confirmation of this mythology, the 1999 subway deaths have been understood to be the latest tragic example of this belief. The reason it is "cursed" is because of the possible identification of the underground river with the old Nemiga river, which is mentioned in the early medieval Slavic epic Tale of Igor's Campaign (Slovo o Polku Igorevom) (Tarasov). According to this epic, in the eleventh century the Kievan Rus undertook a bloody siege of the Polotsk princedom, of which Minsk was then a part. Legendarily, this battle took place on the banks of the Nemiga river. While archeologists and historians argue about whether the Nemiga mentioned in the Slovo and the river in Minsk are actually the same, according to numerous accounts of the event, the prevalent understanding is that the place is "cursed." Another reason for such a belief in urban mythology is that, in the 1950s, an expressway (the Masherov Prospect) was built on the site that many believe was the historical foundation of Minsk (Minsk Old and New). 
Remarkable archival research conducted by Sergey Shapran, a reporter for the Belorusskaya Delovaya Gazeta, contains excerpts from memoirs of the writers and architects involved in discussions about renovating the Upper Town of the Nemiga district. Drawing from the memoirs and archival documents, Shapran resurrects the bureaucratic and intellectual "battles" between the Belarusian intelligentsia and the Soviet municipal authorities about the demolition of that historical part of the city in the 1970s. Older sections that were slated for destruction were composed of buildings and streets from the $16^{\text {th }}$ and $17^{\text {th }}$ centuries. The Nemiga district, a Jewish ghetto during WWII, which claimed the oldest synagogue in Minsk, survived the bombings largely undestroyed (Shapran). In the late 1960s, however, most of the lower part of Nemiga district was demolished by the municipal authorities. In the 1980s, the subway station was built at what archeologists believe to be the site of the early medieval fortress (Tarasov). This part of the Nemiga district features in several movies about WWII, but the ruins actually appearing in the films were the aftermath of postwar demolition explosions (Volozinsky). Thus it was Soviet planners who erased the only important historical district to survive the war intact.

When, in the late 1970s, the plan to "rebuild" the Upper Town as well was approved by Piotr Masherov, First Secretary of the Communist Party of the Belarusian Soviet Socialist Republic,[4] the idea was to "open up" the space in order to see the Svisloch river and the expressway. The plan was to create a "view point" from the largest of the squares and so to enhance a significant part of the Upper Town with staircases and fountains, following the example of imperial St. Petersburg (then Leningrad) (Shapran). The hope was that it would be the largest square in Europe, and planning focused on an abstract display of grandiosity while neglecting how people might actually use or inhabit the spaces. According to Shapran, Masherov, loyal to the ideas of Soviet internationalism, particularly attacked the idea of preserving the $16^{\text {th }}$ - and $17^{\text {th }}$-century buildings, which were associated by the intelligentsia with Belarusian nationalism. Ultimately, the Upper Town was spared, when architects, historical preservationists, and writers pressured Masherov with protest letters and eventually talked him out of it. However, further renovations over the next few decades styled the buildings of the Upper Town (also known as the Trinity Suburb) to "look old." As Galina Siniakova, one of the activists to preserve the Nemiga district in the 1970s, recalls in her letter to the paper Sovietskaya Belorussia, "I understand with great sadness that there will be nothing like the former Nemiga street. And still, I miss the narrow, cobblestone street with its endless shops, which people come to from 
all over the city. What an attractive place it would have been for tourists and residents, maybe a pedestrian zone where people would have enjoyed walking!"

This example asks us to consider the complex intertwining of Lefebvre's three aspects of the production of space, and forms a challenge for describing and theorizing their interconnections. For this space is at the same time actual and representational. The way the place is perceived as a "cursed" place and/or as a medieval historical centre is inseparable from how it is conceived by the urban planners, or from it as an object of nostalgia and personal memories. The archival web-project Minsk Old and New by Vladimir Volozinsky, for example, while producing representations of actual space, also forms representational spaces of Minsk: portraying Minsk through documentary photographs, it is simultaneously involved in the creation of a particular version of the city. It is involved in the production of space by "conceiving" (producing representations of spaces) post-war and contemporary Minsk districts, squares, and streets. The photographs taken after WWII, mostly by Volozinsky's grandfather, also comprise a personal photo-archive, and the chronologically scrupulous descriptions of the city places and streets signify the nostalgic quality of this archive. Old black and white pictures of pre and postwar Minsk, still innocent of the Soviet palaces and gigantic squares, remind us of romanticized representations of smaller European cities like Krakow, with winding, cobblestone streets and low-rise brick buildings. In this archival web-project, which is a form of commemorative practice, the city space of Minsk is simultaneously conceived and perceived as an object of nostalgia for the urban elements that were lost during the Soviet renovations.

The Nemiga district is also represented in numerous debates between the municipal authorities and the civic group formed by the parents and relatives of the victims of the subway catastrophe, Nemiga 99, as well as on internet sites and blogs involved in the construction of the urban memory of the event, including Nemiga 99's website and Minsk Old and New. Their efforts are focused on how the place has been lived, which according to Lefebvre is the third aspect of the production of space, a spatial practice. These struggles bring the social into focus and point to performances of power, grief, and nostalgia, for the memorial also functions as a place of mourning and regular visitation. However, many relatives prefer to go to the cemetery rather than to the memorial. As one of the mothers, Svetlana Belitskaya, says in an interview with a Narodnaya Volia journalist, she does not go to the memorial too often: "That memorial? Whose idea was it to write: fiftythree cuts on the heart of Belarus? This is a cut on my mother's heart. 
On other parents' hearts. No one else's" (Eismont). Like other parents, Belitskaya finds the inscription on the memorial particularly insulting because the state has largely ignored the parents and the memory of their loved ones. President Lukashenko vowed to visit all the parents personally, but, predictably, never got around to it. The parents first asked that the entrance to the subway station where the tragedy occurred be shut down, and hoped to build a small chapel instead, along with a memorial plaque. The municipal authorities only allowed a plaque that lists the names of the victims and a sculptural composition ("Four Years of the Tragedy"). As Natalia Navakovskaya reports, four years after the tragedy the authorities abolished the families' benefits, such as free medicine, transportation, and utilities ("Four Years"). The judicial inquiry was closed and the reason for the tragedy proclaimed "a tragic coincidence." The relatives filed a class action lawsuit accusing the organizers, the sponsors of the concert, the municipality, and the militia of failing to provide safety during a mass gathering. All claims were rejected by the Minsk Municipal Court and the Supreme Court. The parents never received any material compensation (Stepanenko). Because the state refused to admit culpability, they argued, there was no reason to make reparations. For seven years, Nemiga 99 has depended on private donations from the parents to continue. Officially, the Center ceased to exist after it was refused the right to rent a building - an organization cannot "exist" officially without a legal address ("Seven Years"). Another victim's mother, Tamara Nasonova, says: "Nemiga is forgotten. People envy us that we buried our children at the prestigious Moskovskoe cemetery" (Eismont).

Recently, in the Nemiga district, old Soviet patterns of land use are being re-contextualized by contemporary urban policies. This results from a complex interplay of government and of citizens' and corporate interests. The controversial projects for the renovation of this district call for a multi-level parking lot and an underground shopping mall, as well as the reconstruction of the older buildings in order to create the "illusion of an old Minsk street" (Sadovskaya). Apparently, it will involve a complete rebuilding, mimicking the architectural style of the early twentieth century since the "historical buildings" were "lost." What Sadovskaya considers "historical," as well as how and when the buildings were lost, is not specified in her online article. Ironically, this part of the plan is called "Memory of Nemiga."

By linking the three Lefebvrian aspects of the production of space - how space is simultaneously representational, represented and practiced - I have illustrated the ways in which the Nemiga memorial is involved in the production of space in Minsk. The memorial is not 
just a product of collective and individual practices, various discourses, textual and visual representations, but also participates in and is constitutive of the construction of social practices, relations, and representations. As critical geography has largely insisted, space is socially constructed, and the social is spatially constructed as well. In the following section I consider how the city space of enormous squares and Soviet monuments of downtown Minsk, as well as the everyday living spaces of the suburbs, are being continuously produced and transformed through acts of repression, contestation, and liberation, under rapidly changing economic and political conditions, just as they also help to determine what those conditions might come to look like as they produce new social relations.

\section{OKTIABRSKY SQUARE: THE PRODUCTION OF SPACE IN AN AUTHORITARIAN REGIME}

According to Dmitri Zhukov, Oktiabrsky Square was deliberately constructed to avoid public gatherings. During the XXVIII Congress of the Communist Party almost twenty years ago, Zhukov, who was the only Belarusian democratic delegate in attendance, found out while talking to urban planners that the reason for the reconstruction of the Square was simply the Belarusian Soviet Socialist state's authorities annoyance with "the growing of the civic activity of the citizens of Minsk at that time" (Zhukov). The buildings on the Square confirm Zhukov's theory of an "architectural trap." Oktiabrsky Square is an unwelcoming empty space made of concrete in front of a huge building called the Palace of the Republic. 


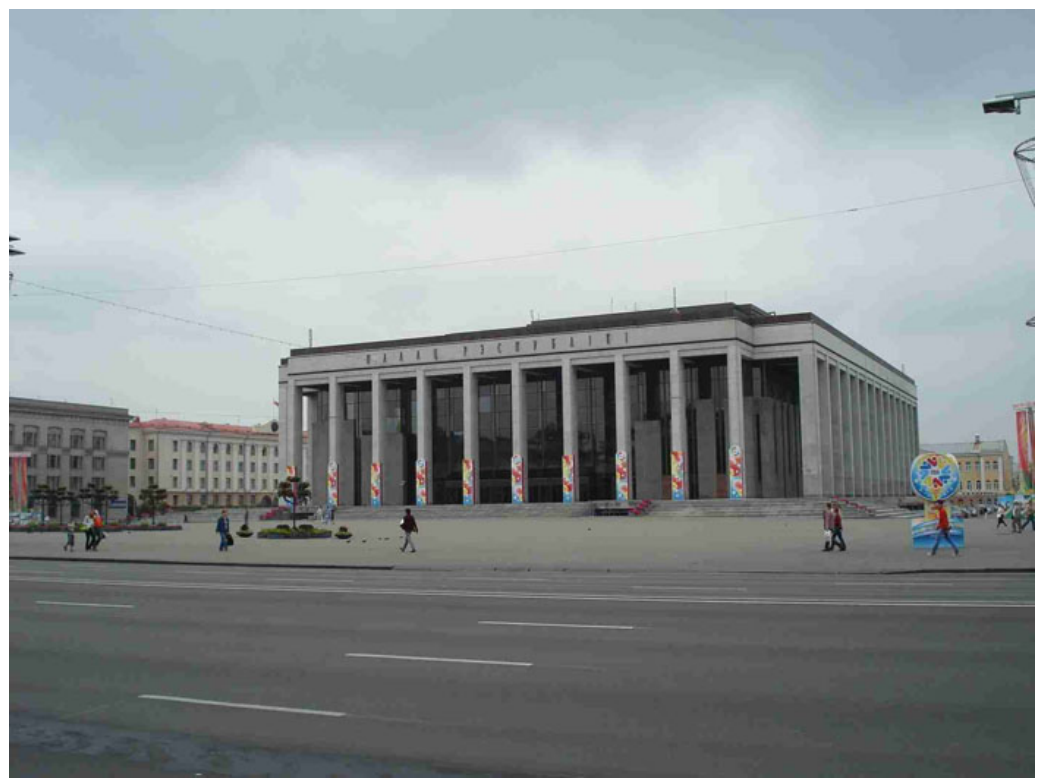

Figure 5. The Palace of the Republic on Oktiabrsky Square.

The Palace of the Republic is a relatively new building; its construction began in 1984 and was completed in 2001. Architecturally, it mimics the pseudo-palaces of Stalinism, such as, for example, the Palace of Culture and Science in Warsaw, with similar ideological connotations. It is a functioning concert hall - "the unique and the main concert hall of the republic," which is used for theatre and orchestra performances, exhibits, New Year's children and parent parties, as well as for business and international conferences, political meetings, official holiday and state awards receptions. The website of the Palace of the Republic calls it more than just a huge building; rather, it is "a live organism stably standing on its own feet." This bodily metaphor is also loaded, as the body itself is a "composite and hierarchized space" (Augé 61), which can be "invaded" by illnesses, with its internal organs functioning as "zones," and so on. If referring to a building that represents power also means referring to power "embodied," then the Palace points to a very specific body: President Lukashenko. In the vernacular the Palace is called a "sarcophagus," and for a good reason: it reminds viewers of a gigantic tomb. The Kremlin Mausoleum in Moscow holds the mummified body of Vladimir Lenin, whereas Minsk's "sarcophagus" to the best of my knowledge does not contain any dead bodies. The body of the president encased in the sarcophagus is not so much dead, however, as eternal (even though he is still alive). Symbolically, the Palace is a 
monumentalization of the presidential body and a mechanism to absolutize state power. It is not important for the totalitarian ideology that the owners of the residence will be changing (in spite of the desire of Lukashenko to envision himself in the residence forever by symbolically securing eternity for himself in the mausoleum); the Palace aims to embody state power forever. If we look at the structure of the building, it is a huge piece of concrete; at night, when the lights are lit on the inside, it creates the illusion of transparency. There is this same transparency in the description of this building on its official website: "to propagandize" the "best achievements of Belarusian and world culture aimed at increasing the moral and cultural level of citizens and aesthetic upbringing of the new generation of the Republic of Belarus" ("The Palace"). Nevertheless, the Palace is the centre of a highly hierarchized space structured by relations of power. The official website emphasizes the building's centrality, placing it in the position of state authority: "The location of the Palace of the Republic underlines its importance and originality once again - the center of the capital" ("The Palace of the Republic"). In the same paragraph, its centrality is underscored once more, in relation to the citizens: "The former Tsentralnaya and now Oktiabrskaya Square is the historical center of the city, which unites all transport and pedestrian flows" ("The Palace of the Republic"). Curiously situated across the street is another "centre": Alexandrovsky Park, where the President's residence is situated.

It is no accident that in the post-Soviet city of Minsk so much attention is given to exteriors: the decorative facades of buildings on the main streets maintain the illusion of order and well-being. "The regime of concealment" of the contemporary Belarusian authoritarian state is perfectly aware of the subversive power of visuality. Such highly visual occurrences as mass demonstrations are violently suppressed by the police. The highest level of combating "bad," contaminating, or "filthy" visuality is the complete physical elimination of disjointing elements: for example, there is no sign on the building aside from the park on Oktiabrsky Square that indicates that this building used to be the Faculty of Theology of the European Humanities University. As Svetlana Boym writes, "The relationship between the Soviet people and their monuments is intimate but often inversely proportional; if monuments appear when people disappear, their gigantism coincides with the shrinkage of human rights. The largerthan-life monuments cast shadows of secrecy over the territories of terror and the operations of power" (88). The city dwellers are then a mass that this place homogenizes through the messages of grandiosity, power and authority; however, there is nothing homogenous 
about a homogenizing place itself: "It is simultaneously limpid and deceptive; in short, it is fraudulent. Falsely true - 'sincere', so to speak; not the object of a false consciousness, but rather the locus and medium of the generation (or production) of false consciousness" (Lefebvre 308-10).

Insofar as citizens are discouraged by diverse visible and invisible power strategies from enjoying the city, from interacting and making the city space their own, these official directives designating appropriate and restricted uses of public spaces never go uncontested. Let me consider how Oktiabrsky Square, while participating in disciplining the city walkers by means of diverse power mechanisms, can also be rendered as a site of resistance and as a place of production of alternative memories, ideologies and identities. The city space in contemporary Minsk not only participates in performances of power and ownership, but also functions as condensations of nostalgia and manifestations of ongoing struggles. It is a "layered" space, composed of urban planning strategies, official discourses, individual routine practices and personal ways of relating to and using city spaces.

On March 19, 2006, presidential elections were held in Belarus, in which President Lukashenko ran against two opposition leaders and won a third term in power. The opposition and international observers pointed to a number of violations during the election campaign, including mass arrests of opposition activists, intimidation of students and employees of state establishments for their political views, unequal access to media, prosecution of independent newspapers and civic institutions, and so on. According to various estimates, between 10,000 and 40,000 people gathered in Oktiabrsky Square to wait for the announcement of the election results. During the next week, protests continued, followed by the organization of a small tent city where protestors stayed and occupied the square. The culmination took place on Saturday, March 25, when a clash occurred between the police and demonstrators. Over 1000 people were sentenced to 15-30 days in prison or fines. Subsequently, many activists were fired from their workplaces and continue to be barred from universities.[5]

Oktiabrsky Square during the March protests can best be understood not simply as a stage for the collision of oppositional political views. During these events, the protesters were actively and experimentally refashioning and producing the meanings of the public sphere, memory, and national identity that opposed official, fixed, and indisputable meanings. New networks of communication led different groups of people to undertake symbolic actions, appropriating the logic of "flash mobs." The idea was that you would show up in the public space of the city, do something fun simultaneously and 
collectively, and go away. According to the Charter97 website, in one case when Belarusian television broadcast its official evening news over a large TV screen in Oktiabrsky Square, people in the crowd put blindfolds over their eyes and turned their backs to the screen. When the militia appeared, they removed their blindfolds and dispersed, rendering them unidentifiable. Another incident took place at the enormous Main Post Office, where crowds formed lines to make payments to the Belarusian Ministry of Finance ("Against Lies and Propaganda"). According to fabricated official reports, protestors had each been paid ten dollars by the European Union to assemble in the square. With this action, protesters were ironically repaying their debt to Belarus. Postal authorities, once they realized what was happening, didn't know exactly what to do or whom to arrest. They asked who was in charge. The interesting aspect of such actions is that there is no central authority; participants are autonomously self-directed, the actions are relatively low risk and aim at embarrassing power and making authorities nervous rather than directly confronting power in "criminal" acts of opposition.

During the existence of the tent city and the marches, people who were not participating kept going about their everyday activities; passing by bus or car or simply walking in Oktiabrsky Square. They witnessed unusual activities, different than in the Square that they were used to: a familiar place suddenly began to seem strange because of these unusual activities. What they witnessed with their own eyes was also radically different from the official representation in the mass media, according to which all people in Belarus are content with the political situation. Some of them discussed what they saw with friends and relatives, some of them joined the protesters. But most importantly, these witnessed protests and "flash mobs" complicated and de-naturalized the relations to everyday routine and intensified everyday practices. The square became (and remains after two years, as the struggles are rewritten and as published recollections appear on various internet blogs and also in online intellectual discussions) a battleground for a variety of identities that processually reconsider national and political affiliations.

\section{MICRODISTRICTS: SOVIET URBAN STRATEGIES AND POSSIBILITIES FOR RE-MAPPING RESISTANCE}

Downtown Soviet Minsk reflects the urban planning strategies of most Soviet capitals: it was rebuilt after WWII and is composed of mostly administrative and cultural buildings, department stores, monuments, etc., with a small proportion of residential housing. The 
majority of the population is concentrated in the suburbs, or microdistricts. These micro-districts are usually centered around a grocery shop, a kindergarten, a hospital, a school and other services such as a library or sports facility, connected by pedestrian walkways. The idea at the core of such an urban planning strategy was to provide equal access to the main elements of urban infrastructure: "People were all to have a wide range of day-to-day needs satisfied within their immediate locality, often within a short walk of where they lived" (Smith $75)$. In practice, however, these micro-districts varied greatly in the access to and quality of services. Historically, the Soviet city centre, in addition to more diverse shops, had more diverse cultural services, such as theatres, galleries, restaurants, and a better transportation system. It also provided spaces for public gatherings, such as parks or squares.

Research on urban planning in the Soviet Union suggests a strange pattern when it comes to post-war Eastern Europe city rebuilding, according to which the city expands not by re-developing already built areas but through the addition of "concentric rings" to the periphery which results in heterogeneous spaces: "Driving from the center of Moscow, one passes through rings of Stalin-era, Khrushchev-era, and Brezhnev-era flats" (Bertaud and Renaud 4). Usually, the residences in the center are of a higher standard and in the Soviet period were occupied by the party elites. Later, in the 1950s under Nikita Khrushchev's urban development reforms, a large number of apartment blocks were constructed that became famous for their poor quality (Smith 78): they were dubbed "khrushchoby" (from the combination of "Khrushchev" and "trushchoby" - slums). Finally, newer developments (usually, cooperative housing from the Brezhnev era) are generally of a better quality and even farther removed from the centre. The patterns of socialist land-use in contemporary Minsk are thus being re-contextualized in an interesting way that often produces a curious layering of classes, times, and styles. For example, it is not unusual to discover wooden village-type farmhouses in the midst of modern multi-storied apartment blocks. 


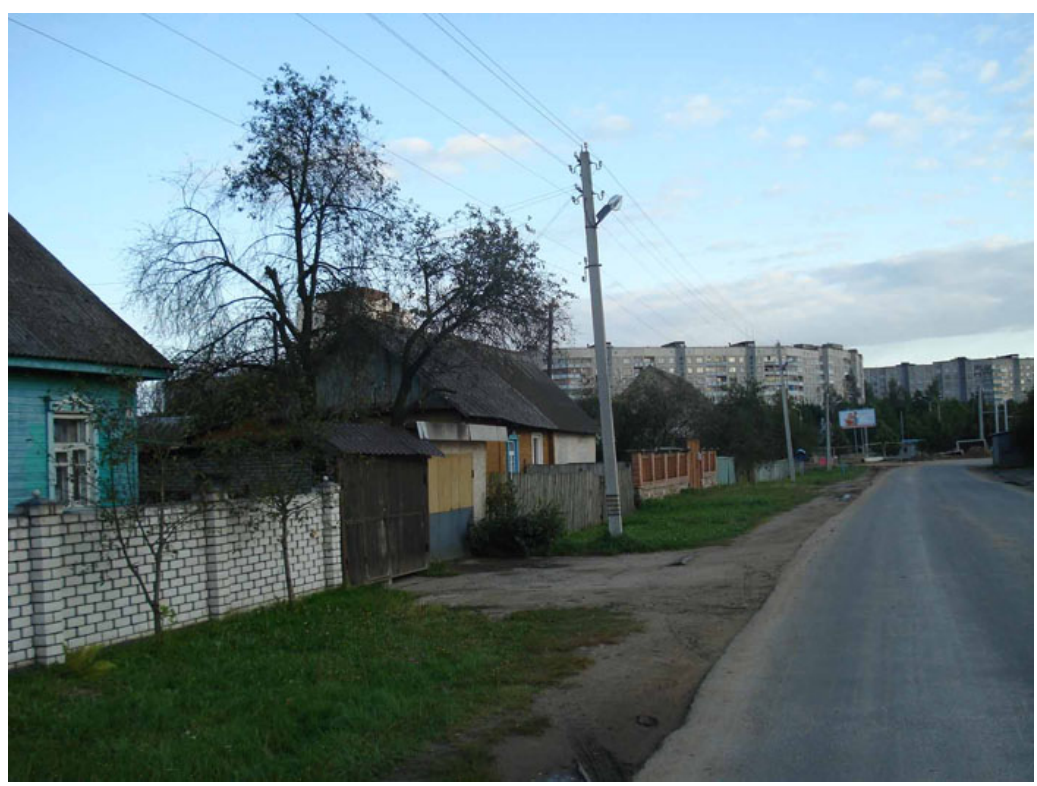

Fig.6. The Wooden Residential Estates.

As Alexander Shkaruba recounts, these so-called "wooden residential estates" became an urban planning strategy after WWII simply to provide people with housing. Made quickly and with cheap materials, this type of housing spread out widely, became something of a city slum, and were largely replaced with apartment blocks in the 1960s (Shkaruba). However, they are still present in Minsk and more so in smaller cities in Belarus and present a visually unusual and somewhat nostalgic sight, especially to a Western (capitalist) eye: idyllic villages, often with a vegetable or fruit garden and some livestock, chickens and horses. Once an ineffective post-war urban planning strategy, in contemporary Minsk these wooden estates now ironically provide unintended resistance to contemporary homogenizing urban strategies (to the best of my knowledge, there is no law protecting these dwellings from demolition because of their historical value).

For today's authoritarian regime it is of extreme importance to maintain the Soviet urban strategy and continue to populate the outer districts, spreading farther and farther from the city's political and public centre. During opposition protest marches, for example, the centre of the city becomes inaccessible for pedestrians: the streets are shut down and transport is "detoured." Most often, the opposition is simply denied the right to protest downtown by City Hall and is "redirected" to the suburbs. Such zoning policies have also been abetted by the rise of capitalism. If it is not the state policies that keep 
populations away from downtown, it is prices, which have skyrocketed since the privatization of housing in the 1990s. The most expensive and prestigious residential properties, according to Realt.by, a Belarussian real estate web-service, are situated in the Zentralny and Sovetsky districts, in the central and northeast parts of the city.

The market pressures and the repressive strategies of the regime provoke extensive re-mappings of alternative city spaces for the articulation of resistance. Suburban parks and water reservoirs become places for public gatherings instead of downtown squares. This rewriting and re-signifying of public spaces has permeated domestic space as well, as private flats and apartment buildings assume new functions. For example, the students of the officially closed Yakub Kolos Lyceum, an elite Belarusian-language high school, have been meeting secretly with their teachers in different private homes for three years. Another example involving flats is the political action developed on Solidarity Day, an initiative of a small community of independent journalists and political activists. It has been held in Belarus since October 2005 in order to express discontent with power and in memory of the numerous politicians, journalists, businessmen, and civil rights activists who have disappeared or been imprisoned during the Lukashenko regime. On the sixteenth of every month at eight p.m. Belarusians are encouraged to turn off the lights in their flats and place a lighted candle in the window.

As capitalist dynamics continue to transform space in Belarus in unprecedented and unpredictable ways, so too must resistance movements learn not just to adapt and occupy the new spaces that emerge but also to participate actively in these very transformations. One way of engaging these problems is to take up and try to resituate the ideas generated by Lefebvre and developed by "critical geographers" in an ongoing active transformation of our own theoretical space, which this paper, in a very humble way, has aimed to do. Incidentally, some of these issues were already anticipated by Lefebvre. Lefebvre criticized the Soviet model for its concentration of economic and political power in the cities, while the "peripheral" areas remain under-developed and "more and more oppressed, controlled and exploited" (421). "The transformation of society presupposes a collective ownership and management of space founded on the permanent participation of the "interested parties,' with their multiple, varied and even contradictory interests. [...] The creation (or production) of a planetwide space as the social foundation of a transformed everyday life open to myriad possibilities" (422). He does not answer the question of how this production of "planet-wide space" might happen. Maybe 
this is something that political activism and active transformations of everyday space are in the process of producing.

\section{NOTES}

[1] All pictures were generously provided by Olga and Vladimir Barykin.

[2] While using a Lefebvrian approach as a tool to analyze the city space of Minsk, it is important to be cautious about abstracting concepts from the contexts in which they originated and applying them instrumentally. Lefebvrian ideas can be examined within the context of the Situationist International, an avantgarde movement of the 1960s and 70s; this project, obviously, cannot be adequately developed in a rather short essay. However, it is important to at least point to the social and political context in Paris in the late 1960s, which was reflected in city policies: "an increased policing of city space under de Gaulle and the wider phenomenon known as 'internal colonization' as seen in the massive displacement of poor populations into new belts of grimly functionalist housing projects at a safe distance from the city centre" (Andreotti 224). The role of the SI in the events of May 1968 is still being debated. However, as Lefebvre's comments on the Situationists in an interview in 1983 indicate, they suggest a connection between play tactics and urban practices in city spaces. The city space in contemporary Minsk not only participates in performances of power, grief and ownership, but also functions as condensations of nostalgia and manifestations of ongoing struggles. It is a "layered" space, composed of urban planning strategies, official discourses, individual routine practices and personal ways of relating to and using city spaces.

[3] For the accounts of the Nemiga tragedy over nine years, see the website of the Charter 97 civic organization, http:/ / www.charter97.org/.

[4] The Soviet equivalent of the President.

[5] For a collection of oppositional as well as pro-Lukashenko news releases and various Internet links on the elections in Belarus, see http:/ / bhtimes.blogspot.com.

\section{WORKS CITED}

"About the Palace." Palace of the Republic. 10 Apr. 2007 <http:/ / www.palace.by>.

"Against Lies and Propaganda." Flashmob on 30 March 2006. Oktiabrsky Square. 20 April 2007 <http:/ / www.charter97.org/bel/news/2006/03/30/ protiv>.

Andreotti, Libero. "Architecture and Play." Guy Debord and the Situationist International: Texts and Documents. Ed. Tom McDonough. Cambridge, MA: MIT Press, 2002. 213-240.

Andrusz, Gregory, Michael Harloe, and Ivan Szelenyi, eds. Cities after Socialism. Urban and Regional Change and Conflict in Post-Socialist Societies. Cambridge, MA: Blackwell Publishers, 1996.

Augé, Marc. "Anthropological Place." Non-Places: Introduction to an Anthropology of Supermodernity. Trans. John Howe. London, New York: Verso Press, 1995. 
Bertaud, Alain, and Bertrand Renaud. "Cities Without Land Markets: Location and Land Use in the Socialist City." Policy Research Working Paper 1477. The Transport Division, Transportation, Water, and Urban Development Department and the Financial Sector Development Department. Washington: World Bank, 1995.

Boym, Svetlana. Common Places: Mythologies of Everyday Life in Russia.. Cambridge, MA: Harvard University Press, 1994.

Clark, Katerina. "Socialist Realism and the Sacralizing of Space." The Landscape of Stalinism. The Art and Ideology of the Soviet Space. Ed. Evgeny Dobrenko and Eric Naiman. Seattle and London: University of Washington Press, 2003. 3-19.

Cooke, Catherine. "Beauty as a Route to the Radiant Future: Responses to the Soviet Architecture." Journal of Design History 10.2 (1997): 137-60.

de Certeau, Michel. The Practice of Everyday Life. Trans. Steven Rendall. Berkeley: University of California Press, 1984.

Dobrenko, Evgeny, and Eric Naiman, eds. The Landscape of Stalinism. The Art and Ideology of Soviet Space. Seattle and London: University of Washington Press, 2003.

Eismont, Maria. "They Were The Best. An Interview with the Parents of the Nemiga Victims." Narodnaya Volia. 28 May 2004. 20 Apr. 2007 <http:/ / www.charter97.org/bel/news/2004/05/28/ best>.

"Four Years of the Nemiga Tragedy." Charter97. 30 May 2005. 18 Apr. 2007 <http:/ / www.charter97.org/bel/news/2003/05/30/ nemiga>.

Golomstock, Igor. Totalitarian Art in the Soviet Union, the Third Reich, Fascist Italy and the People's Republic of China. London: Collins Harvill, 1990.

Groys, Boris. The Total Art of Stalinism. Avant-Garde, Aesthetic Dictatorship, And Beyond. Trans. Charles Rougle. Princeton, NJ: Princeton University Press, 1992.

Huyssen, Andreas. "Present Pasts: Media, Politics, Amnesia." Public Culture 12.1 (2000): 21-38.

Keith, Michael, and Steve Pile. "Introduction: The Politics of Place." Place and the Politics of Identity. Eds. Michael Keith and Steve Pile. New York: Routledge, 1993. 1-21.

Korenko, Dmitri. "Inauguration City." Nashe Mnenie. 10 Apr. 2006. 20 March 2007 <http://nmnby.org/pub/0604/10-j.html>.

Lefebvre, Henri. The Production of Space. London: Basil Blackwell, 1991.

Mann, Robert. Lances Sing: A Study of the Igor Tale. Columbus, OH: Slavica Publishers, 1990.

Marcuse, Peter. "Privatization and Its Discontents: Property Rights in Land and Housing in the Transition in Eastern Europe."In Andrusz and Szelenyi. 119-91.

Massey, Doreen. "Politics and Space/Time." In Keith and Pile, 141-61.

McDonough, Tom. "Situationist Space." Guy Debord and the Situationist International: Texts and Documents. Ed. Tom McDonough. Cambrridge, MA: MIT Press, 2002. 241-266.

Nemiga 99. 2000. 5 March 2007 <http:/ / nemiga99.narod.ru>. 
Nikolaenko, Olena. "Streeet Performances in Non-Democracies: Kyiv During the Orange Revolution." Street Life Conference. University of Toronto, Toronto. 19 Apr. 2007.

Paperny, Vladimir. Architecture in the Age of Stalin: Culture Two. Cambridge University Press, 2002.

"Politmob." Charter97. 7 Apr. 2007. 17 Apr. 2006 <http:/ /www.charter97.org/bel/ news / 2006/04/07/mob>.

Popescu, Monica. "Translations: Lenin Statues, Post-Communism and PostApartheid." The Yale Journal of Criticism 16.2 (2003): 406-23.

Ross, Kristin. "Lefebvre on the Situationists: An Interview." In McDonough. 267-84.

Sadovskaya, Elena. "Businness on Nemiga Street." Arhitektura I Stroitelstvo. 13 Apr. 2005. 15 March 2007 <http:/ / www.ais.by/content/view/446/>.

Scott, Joan. "Experience." Feminists Theorize the Political. Ed. Judith Butler and Joan W. Scott. New York: Routledge, 1992. 22-40.

Shapran, Sergei. "Saving Minsk From Soviet Urban Planners." Belorusskaya Delovaya Gazeta Online 26 Nov. 2004. 10 Feb. 2007 <http:/ / bdg.press.net.by/2004/11/ 2004_11_26.1483/1483_12_1.shtml>.

Shkaruba, Anton. "Sustainability of the Post-Soviet City: Case Study of the Wooden Residential Estates in the City of Mogilev (Belarus)." Belarus State University. Minsk, Belarus.

Silitsky, Vitali. "The Long Road from Tyranny: Post-Communist Authoritarianism and Transitions from Postcommunism." Journal of Democracy 17. 4 (Oct 2006): 138-53.

Siniakova, Galina. "In Search for the Lost." Sovietskaya Byelorussia 46 (22701). 10 Mar. 2007. 8 Apr. 2007 <http:/ / sb.by/article.php?articleID=57258>.

Smith, David M. "The Socialist City." In Andrusz and Szelenyi. 70-99.

Soja, Edward W. Postmodern Geographies: The Reassertion of Space in Critical Theory. New York: Verso, 1989.

---. Postmetropolis: Critical Studies of Cities and Regions. Oxford: Basil Blackwell, 2000.

Tarasov, Konstantin. "On Historical Fate of Nemiga." Interview to Euramost. 17 Oct. 2006. 15 March 2007 < http: / / www.euramost.org/index.php?artc=10024>.

Taylor, Brandon. "Later Soviet Sculpture." Third Text 51 (Summer 2000): 39-50.

Tonkiss, Fran. Space, The City and Social Theory. Cambridge, UK: Polity Press, 2005.

Volozinsky, Vladimir. Minsk Old and New. 2007. 10 May $2007<$ http://www.minskoldnew.com/>.

Zaborowska, Magdalena. "Reading Transparent 'Constructions of History'; or, Three Passages through (In) Visible Warsaw." Over The Wall/After The Fall. Post-Communist Cultures Through an East-West Gaze. Ed. Sibelan Forrester, Magdalena J. Zaborowska, and Elena Gapova. Bloomington and Indianapolis: Indiana University Press, 2004. 97-120.

Zhukov, Dmitri. "Minsk: City of Urban Planning Nonsense." Belorusskaya Delovaya Gazeta Online 19 Sept. 2004. 15 March 2007 <http:/ /bdg.press.net.by/2004/ 10/2004_10_19.1472/1472_9_1.shtml>. 